\title{
Need for Policy Revision: In Context of the United States Defence Strategy Towards South Asia
}

\author{
Vibusha K. Madanayake
}

\begin{abstract}
The twenty-first century globalization in international affairs has created an integration which appears unpreventable. This global integration had an impact on South Asia. This paper examines the significance of the United States defence strategy of combating terrorism and its policy of development. It intends to rethink of the United States defence strategy towards South Asia after September 2001 terrorist attack; whether it is to combat terrorism as stipulated in US national documents or whether it has other intentions. The latter part of this research presents the relevant interventions and defence actions that followed the US policy declarations. The intentions of long-term objectives are implicit in the chain of defence activities that followed to date. In this regard, the significance of this research is to understand how a peaceful atmosphere could be created in South Asia where global development automatically follows. The findings of this research have opened up a relevant and timely topic to inquire into. Specifically, this research encourages Sri Lanka to understand and rethink its foreign policy as a country in a post war period.
\end{abstract}

\section{Keywords}

Globalization, foreign policy, defence, national interest

Many scholars in international relations who investigated into this phenomenon of the modern world observed the US policy of "War on Terror" in 2001 which mainly concentrated upon the military strategy and its related documents such as National Security Strategy 2015. This military strategy was associated with the objective of the development of South Asian region in the political, economic, social, and psychological domains. Obviously, their interests were to secure a hold on Asia against the impact of globalization that had become dominant in the affairs of the world (Stern 2009). The current researcher looks at the behaviour of super powers in a broader perspective than theory explaining the phenomenon which took place after Westphalia. The globalization converted the world into a village. A village meant that the world became a community where its members got close to each other almost brushing their shoulders together. This was the first time that it happened in the history of the world and different ideologies of cultures merged.

Historically, the world was evolving into a globe which was possible to be looked as a close-up network

\footnotetext{
aUniversity of Colombo, Sri Lanka

Correspondent Author:

Vibusha K. Madanayake, No. 348/64, Weerasinghe Pirivena Road, Kirillawala Weboda, 11858, Sri Lanka
} 
of relationships. Nationalism was being challenged through the global expansion of modernist education. Modernism became an ideology through a variety of agencies of communication, media, schools, non-formal relationships, and formal, institutional, and international organizations. Development became the criterion of measurement to justify intervention in the politics of another country. Science and technology had facilitated this path towards the future. Being so, the super power's objectives of the US necessarily add to include the development of the countries they are interfering with, namely South Asia. These countries boarded the Indian Ocean. The coastlines of these countries were important for access to the Indian Ocean. By implication, it was the Indian Ocean that US was interested in. This was clearly seen in the declared policy objective of the US into these countries.

However, South Asia was not geographically integrated region, nor political, historical, or cultural region. The different nation states that surfaced out after the Second World War were super power's creations. For example, India as a currently functional nation state did not exist as a polity nor did Pakistan or Bangladesh previous to the post war super power military interventions. It is the perception of this scenario that prompted the researcher to inquire further through empirical supplications. The body of this research presented is an attempt to find an answer for this argument.

\section{METHODOLOGY AND RESEARCH DESIGN}

The proposed hypothesis to be tested called for a multiple approach to data gathering and theorizing. In this way, the instruments adapted were multifaceted, qualitative, and ethnographic. A construction of an appropriate methodology demanded flexibility in the techniques used for data gathering in an analysis. The subject area comprised of two distinct separate domains. That is "international relations as a science" on one side and the applications of it technologically as foreign policy in scholarly perspective. The nature of international relations in the new global system had to be understood by application of currently prevailing theory, e.g. offense defence theory and hegemonic stability theory.

On the other side, it is the policy factor in international relationships. These relationships are culture bound and are influenced by constructivist ideologies. Right from the beginning of human evolution, the element of using the brain by humans dominated behaviour which was understood as the "human”. In Russell's perspective, it was do of things as different from how of things (Russell 1918). It is this mix up of things how comapred with do's that demanded a method different from clearly compartmentalized in social science methodologies. This approach also carries the characteristic of an interdisciplinary study. Patti Lather points out that all human behaviours are interpretative in research analysis and practically applicable for social change. This means that, developing insights from an ethnographic perspective is meaningful to understand policy formulation. Marx and Engels once criticized all traditional research as meaningless if such research did not promote development to improve the lot of humankind. They brought in the example of male breasts as useless for research. Research should tie up with policy formulation if it is to achieve the objective of improving living conditions. It is in this context this research used the viewpoints of nation's citizens who hold ideas about how nations should relate with other nations. The interviews conducted fulfilled this objective and made this research a combined effort in using substantiated empirical data in a methodological process of policy formulation.

Policies are premeditated and prior to implementation. In similar vein, Carr and Kemmis (1986) stated that, research is meaningless unless it opens the door for policy implementation-policy based on theory. International relations are the 
practical expression of policy on one hand. On the other hand, the discipline of international relations believes in a science based approach and attempts to discover propensities, probabilities, and tendencies in human behaviour when involved in policy construction. This is the major complication in methodology that this research highlights and is faced with.

The idea and the concept of South Asia need explanation. What exists today in South Asia is not what it was right after the Second World War. An unexpected change occurred on the idea and the concept of South Asia. The South Asia at that time was just a geographical reference when focusing attention on the Indian Ocean dominantly in relation to military strategies. However today, South Asia is a loosely knit community with both fission and fusion in relation to social and political change occurring in this geographical region. It had gone through a period of mooting for political and social regionality concerned with a variety of problems faced by these newly sprung independent nation states. The background of South Asia is very different from that of the European community. The South Asian region is evolving and is in massive social change. Exploring to understand the political and economic behaviour of this region has to be within a methodology which will expose the researcher to hitherto unseen realities. Taking into consideration this effect of globalization on international relations' feature, the researcher had to probe into viewpoints of previous scholars who researched on this area. It is with this objective the second part of the methodology developed insights by making ethnographic interviews at meeting among the members of the citizenry at different levels and specializations.

\section{DISCUSSION AND FINDINGS}

The data gathered to arrive at the discussion of US policy for development meet with number of important challenges. South Asia of the present day thinking is very different from what was left in the hands of the super powers from the end of the European conflict among western nations generally referred to as end of the Second World War. An accelerated process of globalization occurred all over the world and international relations between nation states underwent consequential change. When taking into consideration, the result of nations getting closer was a significant factor that caused a challenge. The second was the problem of under-development stagnation and social change due to continuation and construction of traditionalism as against what these societies can achieve as modernity in the new world. Structural adjustments required to adapt to the capitalist economic system are not clearly visible and are a confused picture. International globalization is a new phenomenon without pre-existing models for application to understand how development takes place. One major factor is that research should refer to the moves taken up by the US to prevent the expansion of terrorism into this region. South Asia as a region bordering the Indian Ocean is complex and does not lend itself to analysis as a living community. In the historical process, what we see as US interest is the prevention of terrorism within the Asian countries that border around the Indian Ocean. This is a major challenge posed against the development of these countries. Military strategies refer to the activities in operation within the Indian Ocean. These countries are generally referred to as South Asia. However, these countries exclude the African coastline which also borders the Indian Ocean. This indicates that, US focusing on the Indian Ocean is from the Asian side. Given this condition, it appears that what interests US is the region whose sea line opens into Asia.

The US Policy of the Containment of the Chinese Power

Currently, the US is at the crossroads with Asia. New situations arose after the Second World War and the 
conditions that existed at that time have changed. Structurally, enemies to capitalism that existed in Asia at that time are no more for now. The US still holds its hegemony. The strategies in the military areas in Asia have to be held with great care. Within Asia, the possibility of spreading Soviet communism or even Trotskyism seems diminished. Within the victorious capitalism, the US sees numbers of enemies. These enemies are openly diplomatic and are in constant contact in trade and finance with US itself. But US foreign policy at the present moment is ambiguous. It is because of the suspicion that China may grow into a major power in Asia in the near future. In this context, the US fears that, China may control the economy in Asia. It is a complex condition on which US is trying hard to develop strategies to avert this catastrophe for US hegemony in Asia.

The US stand of their policy attitude was mooted in many media and otherwise discussions. The "String of Pearls" strategy is a geopolitical interpretation of Chinese potential intentions in Asia. It refers to the network of Chinese economic facilities and relationships along its sea lines of communication. This term was originally coined by US scholars themselves to account for China's projected strategies (Marantidou 2014). As Figure 1 below indicates, "pearls" are widespread from the Strait of Hormuz to Strait of Malacca. The international relations experts explain this as a purely commercial strategy of China towards South Asia funded and supported by China such as Gwadar of Pakistan, Hambantota of Sri Lanka, Chittagong of Bangladesh, Sittwe of Myanmar, and Maroa of Maldives. In response to this trade activity, the US Obama Administration 2012 started a strategy called "Pivot to Asia". According to this policy, the US experts to strengthen its ties with Asian states with the objective of gradually promoting Chinese expansion (Campbell and Andrews 2013). In this policy, the US intends to tighten their bonds with India and Pakistan. However, India is a country which conflicted with China regarding the border disputes.
Alongside, US had long history of friendship with Pakistan. These two countries despite their friendships with US are having serious conflict regarding their borders. The research at an interview with an independent scholar by name Chapa Bandara (personal communication, May 3, 2016) stated that "enemy's enemy is a friend". In this way, he explains why US is friendly with both Pakistan and India, but separately. Other scholars interviewed hold different views. Some say that, US strategy is to contain China against Chinese expansion and maintain their continuity in economic hegemony.

According to the way how some scholars interpret the Chinese perspective, the China containment policy is controversial. Donald J. Trump (2016) competing for US presidency was of the view that, "The US is not having any rivalry or competition with China. And the US considers China as the major economic partner to them". The US intellectual and political elites are not agreed and present confused standpoints regarding what policy US should adopt. There is a considerable support to Trump (2016) to view China as a partner to them. The attitudes are mixed with party politics and election programs. According to public citizens' viewpoint in Sri Lanka, which is an important South Asian country, the researcher found out through questionnaires that nearly $56 \%$ held a partial view towards Chinese intervention in Sri Lanka. However, it was also found out that, nearly $90 \%$ of Sri Lankans appreciated the American values and life styles. A fewer percentage about $20 \%$ believe that, both China and US are interested in naval fleet holding Sri Lanka because of the value of Singapore and Sri Lanka's strategic position in the Indian Ocean.

According to Table 1 below, it is very clear that China's economic relationship is important to any country which communicates with China. China represents the biggest share of the US market. In practice, US and China can be interpreted as partners on one hand; US scientific knowledge developing academic and research institutions are important to 


\section{String of Chinese pearls}

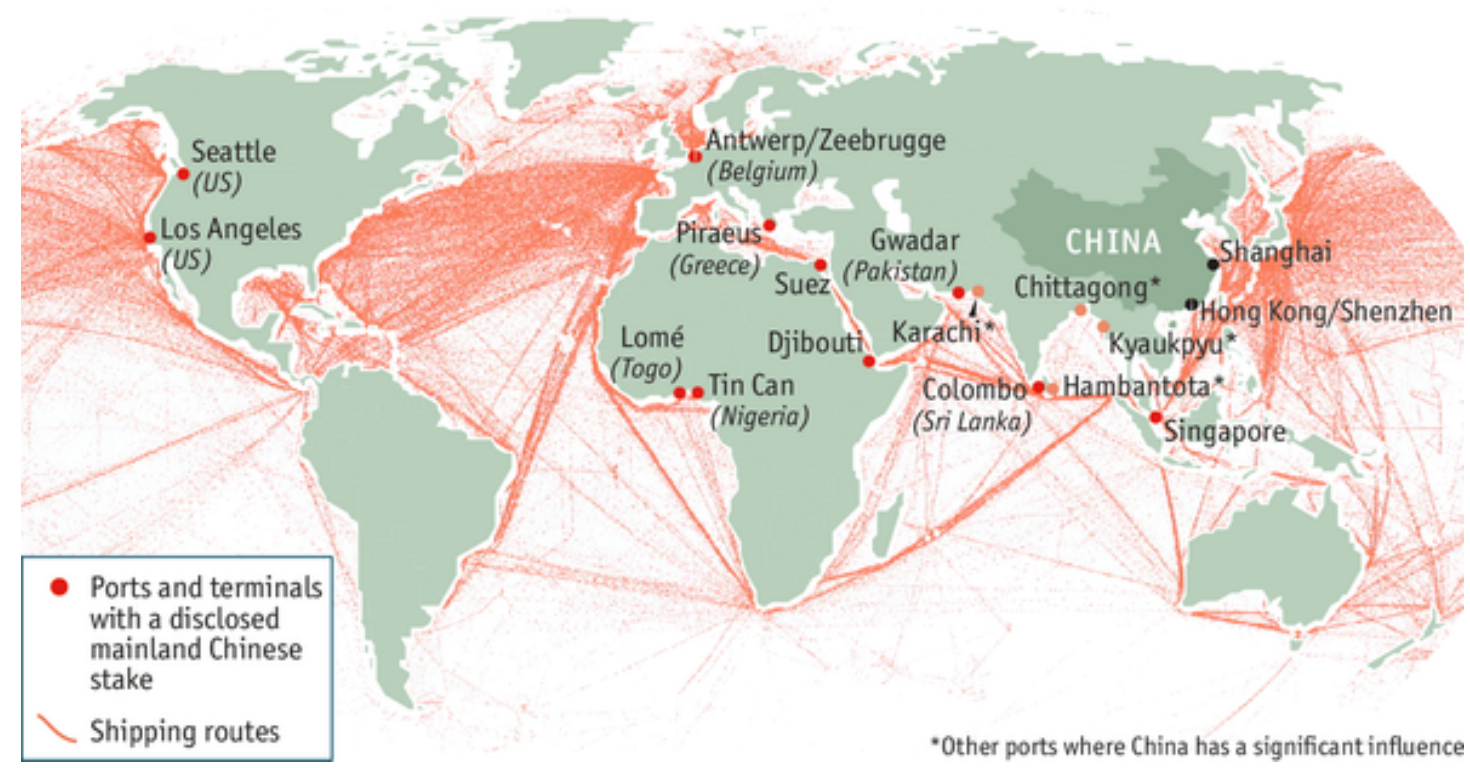

Figure 1. Chinese Strategy of String of Pearls.

Note: Source: Clint, J. S. 2015. What Is the String of Pearls Theory? Quora. Retrieved (https://www.quora.com/ What-is-the-String-of-Pearls-theory-1).

Table 1. Value of Trade Among US, China, and India (In Millions of Dollars)

\begin{tabular}{llll}
\hline Year & India-China trade & India-U.S. trade & U.S.-China trade \\
\hline 2013 & 68,052 & 96,749 & 616,542 \\
2012 & 68,869 & 93,794 & 585,071 \\
2011 & 72,201 & 87,150 & 546,293 \\
2010 & 58,689 & 74,048 & 492,294 \\
2009 & 40,983 & 60,015 & 395,130 \\
2008 & 41,680 & 66,430 & 437,696 \\
2007 & 34,068 & 57,884 & 412,223 \\
2006 & 23,468 & 45,344 & 364,776 \\
2005 & 17,351 & 36,880 & 302,129 \\
2004 & 10,150 & 28,920 & 245,842 \\
2003 & 6,182 & 23,930 & 191,755 \\
2002 & 4,152 & 21,002 & 158,145 \\
2001 & 2,751 & 18,551 & 130,918 \\
2000 & 2,212 & 19,084 & 124,897 \\
\hline
\end{tabular}

Note: Source: Bureau of Economic Analysis, US Department of Commerce (May 2015). Retrieved (https://www.bea.gov/ international/factsheet/).

maintain Chinese trade all over the world. Findings in modern science are difficult to be kept secret. The new technologies arising out of science can be copied, bought over and spy systems can collect information needed to develop modern ways of replacing the old. Given this condition, technological objectives are linked with economic and hegemonic interests of nations. National interest was justified within accepted 
principles of peace, cooperation, and fairness in trade transactions.

\section{Strategic Interest Over Resources and Trade}

With the globalization process in the world, given the prevailing conditions, a new community is emerging for the world. The United Nations established alongside the globalization process was a challenge to many nation states. The challenge was in terms of how the super powers thought about the world. The super powers thought that world peace should be established through outright intervention into warring nations. This was indeed a challenge because behaviourally, globalization meant working together considering each nation as a complete national identity. Alongside, they developed with globalization the spread of political liberalization. The new ideologues developed a viewpoint that capitalism can lead to Nazist authoritarianism or uncontrolled despotism. The idea of liberalism introduced the thought that human identities are global and carry common affinities and attributes. Human beings are equal against nationalities in which race, religion, and language currently dominate. This is a major challenge that the super powers face at intervention into other nations.

Given this condition, political views have to be examined against the way how the resource of the world developed and traded in the common interest of human beings. It is this factor that leads US to define their intervention in Asia as an intervention to promote development. The nineteenth century did not evince any intellectual debate on development and the development was not included in reasons for intervention in other countries. Political institutions of the time did not double with the issue of development. It is with the logic of United Nations that introduced the development ideology and the development decades thereof. In consequence, any intervention by super powers was labelled as the development intervention. US aid was conceived as help to develop and humanitarian because the under-developed world needed humanitarian assistance almost all the time. Development has to do with resource and trade. US intervention in South Asian countries came to be defined as development interventions. This paper analyzes the US strategic military intervention in Indian Ocean in terms of the development objective. The experience of the two great world wars made the US elite think that it could bring continuing peace to the world. The stipulated objective of combating terrorism implied that under development can cause terrorism. This strategy indeed carried strong element of US Aid PL 480, scholarships, and other forms of aid in large amounts intending that it could prevent terrorism by giving a hand to government development programs. American policy supported large NGO activities which helped in the development approved by the government. In different countries, such programs had different names and had different departments for their implementation. Each country had development programs through which these NGOs operated. However, this development approach has been revised and improved according to experience and evaluations made annually to find out whether the objectives have been achieved.

According to the viewpoint of a distinguished diplomat interviewed (personal communication, April 28, 2016), "The United States is more strategic and careful when it wants to manage contending powers like India and Pakistan. Both states are equally important for the US economy”. According to another viewpoint of a journalist by name Vijaya Dissanayake (personal communication, April 29, 2016), "There is an economic motive of every action of the US. The invasion of Afghanistan was also part of the economic game. It is a large scale economic, political, and strategic program. The main objective of this strategy is oil, in other words energy". He refers to most of the wars after 1990 as energy wars. Energy today indeed plays a key role in international politics. The researcher finds "Resource Politics" in South Asia as 
oil politics in the manner it happens in West Asia. A question is raised by the researcher as to whether South Asian countries agree with the continual strengthening of the military strategy definitely. Currently, available research has not been done as of date.

\section{Establishing Democracy and Human Rights}

Democratic government is the major value emphasized in the US foreign policy. The US always calls for a high level of peoples' representation in the government. This is within the boundaries of the principles such as representative governments, public opinion, the constitution, ideology, and education. Education is a technique to achieve this objective which is given prominence by theoreticians. They emphasized values as equality, liberty, and human rights. The US accepts the UN Charter to respect the right of sovereignty in all states. However, if any state challenges on international peace and security, a super power may intervene and openly negotiate with the UN. The major states that hold the right to veto in the Security Council have often resorted to interventions. The veto has functioned as a rescue ground for the institution to continue even if other members descent. This facility is developmental for new attitudes to grow institutions that must change and adopt; because of this condition, one can be very hopeful about the growth of these values through continued negotiation and application.

However, in the case of Sri Lanka, some of the scholars, journalists, and experts were not in the agreement with US intervention in the war partial to the terrorists. At the beginning, they extended military training and strategic assistance to the government of Sri Lanka. However, around the time ending the war, US supported diasporic and Indian intervention for a separate state within a vaguely defined sovereignty. At the beginning, the US CIA was of view that the LTTE (Liberation Tigers of Tamil Eelam) was one of the most dangerous and anti-social terrorist organizations.
Subsequently, US changed its approach and demanded the safe extradition of the terrorist leader into their custody. Sri Lankan government was blamed for war crimes. The UNHRC (United Nations Human Rights Council) is still of the view that Sri Lanka is guilty of war crimes. The research has not met with any data to conclude either viewpoint. This situation has arisen because globalization has setting in motion a machine where information is made available to any interested person. The satellite system can provide operations to check and follow many things that happen on the ground. Media organizations cover detailly every inch of the globe and keep watch on what is happening. However, it is not possible to prevent nation states or super powers using these machines to distort actual happenings. Against this picture of using modern technology, super powers are capable of achieving public support to whatever intention they have in mind.

Running parallel to this, the publicity is given to liberalism and economic equality and these ideologies carry unresolved conflicts within defective institutions which have not been revised in accordance with new values as representative government. The question remains unanswered and that is, "Has the institutions been revised in accordance with the new ideologies maximizing public representation?" This calls for evolutionary changes and this is another instance where globalization is making a demand on traditional institutions. US political institutions were created for internal government in 1776. It followed the principle "No taxation without representation". But over time, taxes grew but not representation. The constitution stalwartly safeguarded the initial kind of representation with which US government began. The globalization process rationally and empirically has made the world a small place and has emphasized on the unity of the human identity as the characteristic global citizenship. There is in this process undercurrent of humanity as a political value. This factor is definitely a challenge faced by the super 
powers or any power who wants to act in their own national interest. More globalization can surface this undercurrent and be a major challenge to "national interest”.

\section{Preventing Nuclear War and Inter-state Conflicts}

According to recent statistics, it is reported that India has 100-120 nuclear warheads. Pakistan has 110-130 (Kronstadt 2004). The US continually tried to convince both India and Pakistan to join the Nuclear Non-Proliferation Treaty (NPT). This happened both within Clinton's administration and after. The US set forth non-proliferation benchmarks for Pakistan and India including the halt of any further nuclear testing. US also called for the Comprehensive Test Ban Treaty (CTBT) halting the production of fissile material. A treaty for the control of fissile material is being negotiated. However, neither Pakistan nor India is signatory in CTBT and NPT. This means that, US faced the problem of getting nations to give up their traditional rivalries. This clearly indicates that there is a risk of nuclear war in the South Asian region. However, some of the critics of international relations are opposed to this point of view. The reason for this criticism is that, US does not make a special effort to redeem conflicts between nations and an element of "divide and rule" exists hiddenly behind US policy. While the US believes in world peace, it comes in conflict with the interest of the US at economic benefit. What is foremost in their South Asian activities is economic interest. It is an ambiguity. One cannot forget the fact that US could be interpreted as keeping South Asia within its national conflicts, inter-state conflicts, or under-development. What we see as the US foreign policy in South Asia, is to sustain South Asia within its conflicts and under-development and in turn eventually swell their own hegemonic power. Asia is only one part of the globe and US can feel that Asia will not pose a threat to their hegemonic power. It is within this context that we can arrive at a conclusion of this research.

\section{CONCLUSIONS}

Working for the defence and the protection of national interest is achieved in international relations by using multiple methods like the military, diplomacy, intrigue, negotiation, persuasion, etc. Militaristic methods are traditionally divided into two categories: defence and offense. In practice and in historical process, these activities are organized into the overall strategy of conducting statecraft. Nevertheless, if the overall defence strategy dominates, it also is a continuing readiness for war. It can contradict the rational national interest of the state which is the individual citizen. The world has come to a stage where the individual citizen is a key focus of all liberal political action. The action of the international society, its community, and the ultimate ideology of human progress would be other aspects in the twenty-first century. This is the dilemma that this research faced at concluding the observations made and the insights that surface from it. The super power conflict and its methodology of hegemonic dominance are confusing. The US is one of the super powers interested in the Asian sea line.

At the beginning of the research, it was hypothesized that the declared objective of interfering in South Asia was an internationally impressive purpose, that was, "combating terrorism”. However, after covering considerable area of accessible literature on the subject, it was concluded that, the policy of combating terrorism or its activity may and could extend over the declared demarcation. It appears that US policy goes beyond combating terrorism. It does not mean that, US policy had hidden agenda with not so pleasant a flavour to the world community.

"War against terrorism" was instituted during the time of the President Bush. There was very little difference in this policy with the coming of President Obama. However, during the time of Clinton, in the previous time of presidency, there was a difference. 
There was a sign of openness and willingness to negotiate during the time of Clinton. But, overall strategies of foreign policy were similar. This could be seen at each historical context of changing governments and difference in trade patterns and economic crisis.

Today, the world is in an accelerated process of international globalization. This is a challenge that the history of the world of traditional directions faces as impediments to progress. A challenge carries obstacles, wayward circumlocutions, and confusion.

This research surfaced out some of these manifestations of globalization. The researcher finds a need for a paradigm shift (Khun 1962) to explain the phenomenon of these new emerging changes. US defence strategy in Asia meets with this challenge. US called their strategy a development aid for Asia. But, the proximity of men, women, children, and nation in one whole under the process of globalization disturbs this scenario. The world is something like what a village was in traditional society. In the traditional societies of the past and its continuing legacies into the twenty-first century, it is this village which possesses this challenge. Development demands the transference into modernity from the vestiges of traditions that lay widely in Asia. Globalization has created this new community which needs new structures of effective democratization, liberal economic, and social equality. In this context, research raises a question, that is, "What has the super power done to make this new community democratic?”. US has given a number of aid programs like US Aid PL 480 , concessions on wheat, milk, etc. But, it is yet to find out whether US strategies concentrated sufficiently to install a major attitudinal change to promote a spirit of sustainable development. Theoreticians believe that, the world will realize that if the producers are to sustain, they will have to satisfy the consumer. Unless they satisfy the consumer, the development of democracy and effective representation can overthrow the ruling elites. The ruling elites of USA are capitalists comprising those who dabble in maximizing profits. Globalization has brought in a social circumstance where everybody in the world can meet, will meet and strive to achieve more and more representation of common interest. Common interests reflect the wishes of the individual. The individual is the global person who is a liberal, rational, and empirical personality of world citizenship. They get together every day and get closer and closer in their dealings. Getting together, they will be more and more powerful and constrain the directions of foreign policy in their interest. This can cause a major obstacle to super power intervention in South Asia. This is a major challenge from international globalization.

The researcher as a member of a South Asian country finds meaning in inquiring into this topic area. It should finally justify the way how it contributes to foreign policy. Foreign policy today in this modern world affects almost everyone in the international community. Humanity is the total coverage of this foreign policy. Sri Lanka as one of the South Asian countries is relevant to this issue of US strategy in Asia. More and more data can help produce a fruitful and active public interest and thereby contribute to a public viewpoint based on the realities discovered by the research. Public opinion can in turn influence policy making at the level of political elites currently operating in Sri Lanka.

\section{Acknowledgements}

The researcher has the honor to take this opportunity to express her gratitude to each and every one who supported and guided her to complete this paper successfully. First, the researcher is very much obliged in the first instance to her supervisor Ms. Kulani Wijayabahu, lecturer of Department of International Relations, University of Colombo for the guidance and help who gave her to begin, progress, and complete this research paper. Ms. Kulani Wijayabahu's patience, kindness, motivation, immense knowledge, and constant surveillance of the researcher's work indeed led to the successful completion of the research. The researcher also extends her special thanks to 
Mr. Asanga Abeygoonasekera, director general at the Institute of National Security Studies Sri Lanka (Ministry of Defence, Sri Lanka) who advised her and encouraged her always. Mr. Asanga Abeygoonasekera was indeed a source of untold help and guidance. Further, the researcher is very much thankful to former diplomatic officer and lately research fellow at the National Institute of Education, Sri Lanak, Mr. Hemachandra Wijesooriya for his guidance. The researcher appreciates the long discussions that helped her sort out technical details of a research work. The researcher's sincere gratitude is also extended to the librarian of Regional Centre of Strategic Studies (RCSS) Mrs. Kamani Perera and the librarian of the American Centre who gave her helping hand with bunches of information on books in the preparation of this dissertation. The researcher also wishes to express her sincere thanks to all the distinguished diplomats, university lecturers, scholars, international relations experts, and journalists who gave her personal interviews to make this effort a success. The researcher is also thankful to the public who responded her and supported her in her survey of the Sri Lankan viewpoint on the US defence strategy towards South Asia. Most importantly, none of this would have been possible without the love and patience of the researcher's family. Therefore, she would like to express her heartiest gratitude to her mother and father. They have been a constant source of love and concern, support and strength all these years.

\section{References}

Bilton, T., K. Bonnett, P. Jones, T. Lawson, D. Skinner, M. Stanworth, and A. Webster. 1996. Introductory Sociology. London: Macmillan.

Campbell, K. and B. Andrews. 2013. Explaining the US "Pivot" to Asia. Retrieved (https://www.chathamhouse.org/sites/ files/.../0813pp_pivottoasia.pdf).

Carr, W. and S. Kemmis. 1986. Becoming Critical: Education, Knowledge and Action. London: Routledge Farmer.

Confederation of Indian Industry. 2009. India-USA Economic Relations, the Next Decade. Retrieved (http://www.cccindia. co/indiausa_economic.pdf).

Daalder, I. H. and M. L. James. 2003. America Unbound: The Bush Revolution in Foreign Policy. Washington, D.C.: Brookings Institution Press.

Khun, T. 1962. The Structure of Scientific Revolutions. Chicago: University of Chicago Press.

Kronstadt, K. A. 2004. Pakistan-U.S. Relations. Retrieved (http://carnegieenowment.org/pdf/npp/uspakistan.pdf).
-2009. US-India Relations. Retrieved (http://www. fas.org/sgp/crs/row/RL33529.pdf).

Marantidou, V. 2014. "Revisiting China's 'String of Pearls' Strategy: Places 'With Chinese Characteristics' and their Security Implications.” Pacific Forum CSIS Issues and Insights 14(7). Retrieved (https://www.files.ethz.ch/isn/182 061/140624_issuesinsights_vol14no7.pdf).

McNeill, P. 1992. Research Methods. New York, NY: Routledge.

Russell, B. 1918. Proposed Roads to Freedom: Socialism, Anarchism and Syndicalism. Retrieved (http://pinkmonkey. com/dl/library1/digi311.pdf).

Stern, R. M. 2009. World Scientific Studies in International Economics. Chennai: World Scientific Publishing Company.

Trump, D. J. 2016. Reforming the U.S.-China Trade Relationship to Make America Great Again. The Trump Organization. Retrieved (https://www.donaldjtrump.com/ positions/us-china-trade-reform).

Tull, D. M. 2006. “China's Engagement in Africa: Scope, Significance and Consequences." J. of Modern African Studies 44(3):459-479. Retrieved (http://archives.cerium.ca/ IMG/pdf/Tull.pdf).

U.S.-Pakistan Business Council. 2009. Strengthening the U.S.-Pakistan Economic Partnership: Policy Recommendations to the Obama Administration and to Members of Congress. Retrieved (https://www.uschamber. com/sites/default/files/legacy/reports/0903_uspakistan_opt. pdf).

Vaughn, B. 2011a. Nepal: Political Developments and Bilateral Relations With the United States. Congressional Research Service. Retrieved (https://fas.org/sgp/crs/row/ RL34731. pdf).

—. 2011b. Sri Lanka: Background and U.S. Relations. Retrieved (https://fas.org/sgp/crs/row/RL31707.pdf).

White House. 2015. National Security Strategy of the United States of America 2015. Retrieved (https://www.whitehous e.gov/sites/default/files/docs/2015_national_security_strate gy.pdf).

\section{Bio}

Vibusha K. Madanayake, studying master in International Relations, University of Colombo, Sri Lanka, research assistant, Institute of National Security Studies Sri Lanka (Ministry of Defence, Sri Lanka); research fields: foreign policy, geopolitics, US studies, South Asian stuides, youth development. 